\title{
The role of subpolar deep water formation and Nordic Seas overflows in simulated multidecadal variability of the Atlantic meridional overturning circulation
}

\author{
K. Lohmann ${ }^{1}$, J. H. Jungclaus ${ }^{1}$, D. Matei ${ }^{1}$, J. Mignot ${ }^{2,3}$, M. Menary ${ }^{4}$, H. R. Langehaug ${ }^{5,6}$, J. Ba ${ }^{7}$, Y. Gao ${ }^{5,6}$, \\ O. H. Otterå ${ }^{6,8}$, W. Park ${ }^{7}$, and S. Lorenz ${ }^{1}$ \\ ${ }^{1}$ Max Planck Institute for Meteorology, Hamburg, Germany \\ ${ }^{2}$ LOCEAN, Institute Pierre Simon Laplace, University Pierre and Marie Curie, Paris, France \\ ${ }^{3}$ Climate and Environmental Physics, and Oeschger Centre of Climate Change Research, University of Bern, \\ Bern, Switzerland \\ ${ }^{4}$ Met Office Hadley Center, Exeter, UK \\ ${ }^{5}$ Nansen Environmental and Remote Sensing Center, Bergen, Norway \\ ${ }^{6}$ Bjerknes Centre for Climate Research, Bergen, Norway \\ ${ }^{7}$ Helmholtz Centre for Ocean Research Kiel, Kiel, Germany \\ ${ }^{8}$ Uni Research, Bergen, Norway \\ Correspondence to: K. Lohmann (katja.lohmann@mpimet.mpg.de)
}

Received: 18 September 2013 - Published in Ocean Sci. Discuss.: 30 October 2013

Revised: 6 February 2014 - Accepted: 26 February 2014 - Published: 14 April 2014

\begin{abstract}
We investigate the respective role of variations in subpolar deep water formation and Nordic Seas overflows for the decadal to multidecadal variability of the Atlantic meridional overturning circulation (AMOC). This is partly done by analysing long (order of 1000 years) control simulations with five coupled climate models. For all models, the maximum influence of variations in subpolar deep water formation is found at about $45^{\circ} \mathrm{N}$, while the maximum influence of variations in Nordic Seas overflows is rather found at 55 to $60^{\circ} \mathrm{N}$. Regarding the two overflow branches, the influence of variations in the Denmark Strait overflow is, for all models, substantially larger than that of variations in the overflow across the Iceland-Scotland Ridge. The latter might, however, be underestimated, as the models in general do not realistically simulate the flow path of the Iceland-Scotland overflow water south of the Iceland-Scotland Ridge. The influence of variations in subpolar deep water formation is, on multimodel average, larger than that of variations in the Denmark Strait overflow. This is true both at $45^{\circ} \mathrm{N}$, where the maximum standard deviation of decadal to multidecadal AMOC variability is located for all but one model, and at the more classical latitude of $30^{\circ} \mathrm{N}$. At $30^{\circ} \mathrm{N}$, variations in
\end{abstract}

subpolar deep water formation and Denmark Strait overflow explain, on multimodel average, about half and one-third respectively of the decadal to multidecadal AMOC variance. Apart from analysing multimodel control simulations, we have performed sensitivity experiments with one of the models, in which we suppress the variability of either subpolar deep water formation or Nordic Seas overflows. The sensitivity experiments indicate that variations in subpolar deep water formation and Nordic Seas overflows are not completely independent. We further conclude from these experiments that the decadal to multidecadal AMOC variability north of about $50^{\circ} \mathrm{N}$ is mainly related to variations in Nordic Seas overflows. At $45^{\circ} \mathrm{N}$ and south of this latitude, variations in both subpolar deep water formation and Nordic Seas overflows contribute to the AMOC variability, with neither of the processes being very dominant compared to the other. 


\section{Introduction}

The strength of the Atlantic meridional overturning circulation (AMOC) significantly influences the climate in northwestern Europe through the associated northward heat transport (e.g. Hall and Bryden, 1982). A detailed understanding of the processes that govern the AMOC variability is therefore a topic of much interest. In particular, the respective role of deep water formation variability north and south of the Greenland-Scotland Ridge (GSR) in modulating the AMOC strength is still not fully understood.

Several studies based on multicentury-long control simulations with coupled climate models (e.g. Bentsen et al., 2004; Jungclaus et al., 2005; Msadek and Frankignoul, 2009; Medhaug et al., 2012; Escudier et al., 2013) suggest that AMOC variability is closely linked to convective mixing in the subpolar North Atlantic, but not strongly related to convective mixing in the Nordic Seas. Using multicenturylong control simulations with 10 coupled climate models, Ba et al. (2014), however, find in some of the models significant correlation between AMOC variability and convective mixing in the Nordic Seas. Since the source waters of the overflow water masses at the GSR are relatively complex (e.g. Tanhua et al., 2008; Våge et al., 2013), variations in Nordic Seas convection do not necessarily match with variations in the overflows across the GSR. In the CCSM4 (Community Climate System Model) preindustrial control simulation (Danabasoglu et al., 2012), AMOC variability is primarily driven by deep convection changes in the Labrador Sea. Increased overflow transports from the Nordic Seas do not lead to a stronger AMOC, but rather appear to be a precursor to a weaker AMOC through enhanced stratification in the Labrador Sea. In contrast, Köhl and Stammer (2008), using an ocean reanalysis for the last 50 years, find a high correlation of the AMOC variability at $48^{\circ} \mathrm{N}$ with the Denmark Strait overflow as well as with the density at intermediate depth south of the Denmark Strait, but a low correlation with the convective mixing in the Labrador Sea. Based on a 50 year-long simulation with a coupled model of the Arctic-North Atlantic Ocean, Bailey et al. (2005) find that the AMOC variability is well correlated with the integrated surface heat flux over the Labrador Sea. Their model simulation, however, has a shortage of buoyant surface water, leading to an overly strong convection. Using a regional model for the Atlantic Ocean forced with atmospheric reanalysis fields, Böning et al. (2006) show that convection events in the Labrador Sea are followed by a strengthening of the AMOC. Their model configuration, however, excludes changes in the Nordic Seas overflows by imposing climatological conditions at the northern boundary. Based on observations, Latif et al. (2006) suggest that the Atlantic dipole sea surface temperature anomaly index over the last century, which is a fingerprint for AMOC variability (Latif et al., 2004), is a response to the North Atlantic Oscillation and associated changes in Labrador Sea convection. Based on relations derived from ocean-only simulations, they estimate, however, that the observed changes in the density of the Denmark Strait overflow over the last decades translate into AMOC changes that are of comparable order as the AMOC variability associated with Labrador Sea convection during the last century. We note that the respective role of subpolar deep convection and Nordic Seas overflows has also been discussed regarding the intensity of the subpolar gyre (e.g. Levermann and Born, 2007, using a coupled climate model). This question remains nevertheless also widely open.

Here we investigate the respective role of deep water formation variability north and south of the GSR for the lowfrequency AMOC variability at different latitudes in the North Atlantic in a multimodel framework by analysing long (order of 1000 years) control simulations with five coupled climate models. Different from some of the previous studies mentioned above (e.g. Bentsen et al., 2004; Jungclaus et al., 2005; Msadek and Frankignoul, 2009; Escudier et al., 2013; Ba et al., 2014), we use the thickness of Labrador Sea Water and the strength of the Nordic Seas overflows rather than convective mixing as indicators for deep water formation south and north of the GSR respectively. The Labrador Sea Water thickness and Nordic Seas overflow strength have a more direct effect on the AMOC. Regarding the Nordic Seas overflows, we consider the transport both through the Denmark Strait and across the Iceland-Scotland Ridge. The influence of the latter on the AMOC variability has so far received little attention in the literature. Based on control simulations, the influence of subpolar deep water formation and Nordic Seas overflow variations on the AMOC variability can only be estimated by means of statistical analysis. In order to more directly estimate the influence of these two processes, we perform and analyse two sensitivity experiments with one of the models, in which we artificially suppress the variations in either subpolar deep water formation or Nordic Seas overflows.

In this study, we focus on the decadal to multidecadal AMOC variability. Variability on other timescales, such as centennial or multicentennial, can be found in previous studies: Fischer (2011) discusses centennial variability of AMOC, subpolar deep water formation and Nordic Seas overflows in a 6000 year-long transient Holocene simulation with the MPI coupled climate model applying the same grid configuration as MPI-ESM-CR (Max Planck Institute for Meteorology Earth System Model). Park and Latif (2008) suggest that multidecadal AMOC variability in the KCM (Kiel Climate Model) control simulation originates in the North Atlantic, whereas multicentennial variability is driven by the Southern Ocean. Menary et al. (2012) link centennial AMOC variability in the HadCM3 (Hadley Center Climate Model), KCM and MPI-ESM-CR control simulations to a meridional shift in the intertropical convergence zone and the advection of the associated salinity anomalies into the deep water formation regions. Regarding the seasonal to interannual AMOC variability, according to the literature, it appears 
to be mainly wind-driven through local Ekman transport (e.g. Köhl, 2005; Biastoch et al., 2008).

The paper is organised as follows: the coupled climate models and the simulated state in the North Atlantic are described in Sect. 2. In Sect. 3, we present the analysis of the multimodel control simulations. In Sect. 4, the sensitivity experiments with one of the models are presented. We discuss the results and summarise the main conclusions in Sect. 5.

\section{Model description and simulated state in the North Atlantic Ocean}

We analyse millennial-scale control simulations with five global, coupled climate models; namely the MPI-ESM-CR (Jungclaus et al., 2010), the KCM (Park and Latif, 2008; Park et al., 2009), the coupled climate model developed at the Institute Pierre-Simon Laplace (IPSLCM4 v2, hereafter IPSLCM4; Marti et al., 2010; Servonnat et al., 2010), the HadCM3 (Gordon et al., 2000; Pope et al., 2000) and the Bergen Climate Model (BCM; Furevik et al., 2003; Otterå et al., 2009). These simulations were available within the EU project THOR (ThermoHaline Overturning - at Risk?). We limit our study to simulations from the project partners, as non-standard model output, such as the overflow transports across the GSR, is needed. The models use relatively coarseresolution grid configurations and are sufficiently computationally efficient to perform long simulations (1000 years, BCM 700 years), allowing robust results on decadal to multidecadal timescales. The horizontal resolution in the North Atlantic is of the order of $100 \mathrm{~km}$. We also include a control simulation with a higher-resolution grid configuration in this study: a 500 year-long control simulation with a previous version of the MPI coupled climate model (MPI-AO-LR; Jungclaus et al., 2006) with an approximately double-resolution grid configuration compared to MPI-ESM-CR. An overview of the model configurations used in this study is given in Table 1.

Regarding the simulated AMOC and North Atlantic climate variability, recent multimodel control simulation studies (including many of the simulations used here) discuss differences among the various coupled climate models in both the representation of the low-frequency North Atlantic climate variability as well as in the mechanisms and feedbacks involved (e.g. Menary et al., 2012; Langehaug et al., 2012b; Gastineau and Frankignoul, 2012; Ba et al., 2014).

The overall maximum AMOC strength in the North Atlantic in the different control simulations (Fig. 1) varies between about 10 and $21 \mathrm{~Sv}$ ( 1 Sverdrup $=10^{6} \mathrm{~m}^{3} \mathrm{~s}^{-1}$ ); and is located at a depth of about $1000 \mathrm{~m}$ between 30 and $35^{\circ} \mathrm{N}$, with the exception of IPSLCM4, where it is located at $45^{\circ} \mathrm{N}$. Compared to the observational estimate at $26.5^{\circ} \mathrm{N}$ (Cunningham et al., 2007; Kanzow et al., 2010), suggesting a mean AMOC strength of about $18.5 \mathrm{~Sv}$ with an interannual variability of about $\pm 2 \mathrm{~Sv}$, the simulated AMOC strength lies
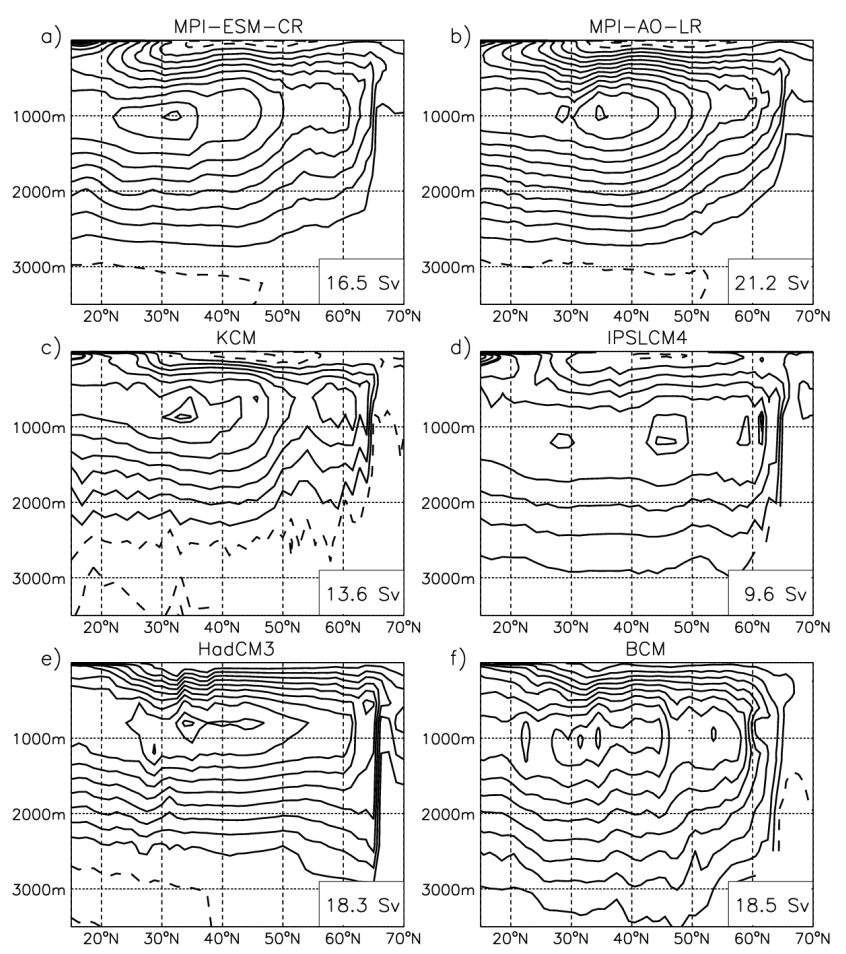

Fig. 1. Mean Atlantic meridional overturning streamfunction (in Sv) in the control simulation with (a) MPI-ESM-CR, (b) MPI-AO-LR, (c) KCM, (d) IPSLCM4, (e) HadCM3 and (f) BCM. Solid (dashed) lines indicate positive (negative) values. Contour interval is $2 \mathrm{~Sv}$, starting from $\pm 1 \mathrm{~Sv}$. An additional contour line is added to show the respective location of the overall maximum strength. The respective value of the overall maximum strength is given in the lower right corner.

within the observed range at this latitude in all models except for KCM (13 Sv) and IPSLCM4 (9Sv). For IPSLCM4, we note that the AMOC strength is drifting throughout the simulation due to a relatively short spin-up phase. Most of the models show a too shallow meridional overturning cell. This is indeed a common problem in $z$ coordinate models due to unrealistically large diapycnal mixing associated with the Nordic Seas overflows (e.g. Willebrand et al., 2001; Danabasoglu et al., 2010; Yeager and Danabasoglu, 2012). The excessive mixing results in a density of the simulated overflow water masses which is too low compared to observations. The simulated lower branch of the AMOC extends below $3000 \mathrm{~m}$ only in BCM - the only model using an isopycnic vertical coordinate.

We have determined the dominant periodicity of decadal to multidecadal AMOC variability at different latitudes in the North Atlantic in the various control simulations based on peaks in the power spectra exceeding the $95 \%$ confidence level when compared to a red-noise process. The AMOC strength at a particular latitude, we define as the maximum value of the Atlantic meridional overturning streamfunction over all depth levels at that latitude. The dominant 
Table 1. Overview of the coupled climate models used in this study.

\begin{tabular}{|c|c|c|c|c|c|c|c|c|}
\hline Model & $\begin{array}{l}\text { Ocean } \\
\text { component }\end{array}$ & $\begin{array}{l}\text { Atmosphere } \\
\text { component }\end{array}$ & Ocean grid & $\begin{array}{l}\text { Resolution in } \\
\text { North Atlantic }\end{array}$ & Atmosphere grid & Ocean levels & $\begin{array}{l}\text { Atmosphere } \\
\text { levels }\end{array}$ & $\begin{array}{l}\text { Length of } \\
\text { control } \\
\text { simulation }\end{array}$ \\
\hline MPI-ESM-CR & MPI-OM & ECHAM5 & $\begin{array}{l}\text { conformal } \\
\text { mapping, } 3^{\circ} \text {, } \\
\text { northern pole } \\
\text { over Greenland }\end{array}$ & $50-200 \mathrm{~km}$ & spectral, T31 ${ }^{\mathrm{a}}$ & $40 z$-levels & 19 & 1000 years \\
\hline MPI-AO-LR & MPI-OM & ECHAM5 & $\begin{array}{l}\text { conformal } \\
\text { mapping, } 1.5^{\circ} \text {, } \\
\text { northern pole } \\
\text { over Greenland }\end{array}$ & $25-100 \mathrm{~km}$ & spectral, T63* & $40 z$-levels & 31 & 500 years \\
\hline KCM & $\mathrm{NEMO}^{\mathrm{b}}$ & ECHAM5 & $\begin{array}{l}\text { conformal } \\
\text { mapping, } 2^{\circ} \text {, } \\
\text { tripolar } \\
(\text { ORCA2 grid) }\end{array}$ & $100-200 \mathrm{~km}$ & spectral, T31 ${ }^{\mathrm{a}}$ & $31 z$-levels & 19 & 1000 years \\
\hline IPSLCM4 & OPA 8.2 & LMDz4 & $\begin{array}{l}\text { conformal } \\
\text { mapping, } 2^{\circ} \text {, } \\
\text { tripolar } \\
\text { (ORCA2 grid) }\end{array}$ & $100-200 \mathrm{~km}$ & $\begin{array}{l}3.75^{\circ} \text { (long) } \times \\
2.535^{\circ} \text { (lat) }\end{array}$ & $31 z$-levels & 19 & 1000 years \\
\hline HadCM3 & No specific name & HadAM3 & $\begin{array}{l}1.25^{\circ} \times \\
1.25^{\circ}\end{array}$ & $\sim 100 \mathrm{~km}$ & $\begin{array}{l}3.75^{\circ} \text { (long) } \times \\
2.5^{\circ} \text { (lat) }\end{array}$ & $20 z$-levels & 19 & 1000 years \\
\hline $\mathrm{BCM}$ & MICOM & ARPEGE & $\begin{array}{l}\text { conformal } \\
\text { mapping, } 2.4^{\circ} \text {, } \\
\text { northern pole } \\
\text { over Siberia }\end{array}$ & $150-200 \mathrm{~km}$ & spectral, T63 & $\begin{array}{l}34 \text { isopycnic } \\
\text { layers, non- } \\
\text { isopycnic } \\
\text { surface } \\
\text { mixed layer }\end{array}$ & 31 & 700 years \\
\hline
\end{tabular}

${ }^{\mathrm{a}}$ Corresponding to about $3.75^{\circ}\left(1.875^{\circ}\right.$ ) on a Gaussian grid for T31 (T63). ${ }^{\mathrm{b}} \mathrm{NEMO}$ (Nucleus for European Modelling of the Ocean) is based on the OPA model.

periodicity varies among models and latitudes and provides a rather wide range of variability from decadal to multidecadal timescales (20-75 years). Furthermore, Zanchettin et al. (2010, their Fig. 2), using the MPI-ESM-CR control simulation, and Menary et al. (2012, their Fig. 1), using the HadCM3, KCM and MPI-ESM-CR control simulations, show that the dominant periodicity of AMOC variability at $30^{\circ} \mathrm{N}$ is non-stationary in time. To focus on the decadal to multidecadal timescales, we apply a 10th-order Butterworth bandpass filter for periods ranging from 15 to 80 years to all model data. In the following, we refer to this variability as multidecadal variability.

The mean mixed layer depth (MLD) in March, which indicates the location of deep water formation, differs among the various control simulations (Fig. 2). Deep convection in or off the Labrador Sea is found in MPI-ESM-CR, MPI-AOLR and BCM. Compared to the observed winter convection depth in the Labrador Sea, which varies from about 800 to $2300 \mathrm{~m}, \mathrm{MPI}-\mathrm{AO}-\mathrm{LR}$ and KCM show a relatively large convection depth exceeding $2500 \mathrm{~m}$ in the mean. Apart from deep convection in the Labrador Sea, observations show relatively shallow convection in the Irminger Sea, with a winter convection depth generally not exceeding $500 \mathrm{~m}$. Shallow convection in the Irminger Sea is also found in all models except for KCM and IPSLCM4. In the latter two models, deep convection is shifted south of Iceland. Regarding BCM, where an isopycnic vertical coordinate is used, MLD is not the best indicator for deep water formation (Medhaug et al., 2012). We note, however, that in our definition of subpolar deep water formation variability in BCM, the MLD is not taken into account.

For the definition of a subpolar deep water formation index, we follow Zhu and Jungclaus (2008), using the thickness of Labrador Sea Water. Nevertheless, due to the varying location of subpolar deep water formation in the different models (Fig. 2), we use the expression subpolar deep water, rather than Labrador Sea Water, in the present study. A description of how we determine the thickness of subpolar deep water in the different models is given in Appendix A. As an index for subpolar deep water formation (SDWI), we average the annual thickness of subpolar deep water over the subpolar region $\left(60-15^{\circ} \mathrm{W}\right.$ and $\left.45-65^{\circ} \mathrm{N}\right)$. The entire subpolar region is chosen to account for the different location of the subpolar deep water formation in the various models. Based on the MPI-ESM-CR control simulation, we have also tested defining the SDWI by using the subpolar deep water thickness in March or by averaging the subpolar deep water thickness over the convection region (defined by the grid cells where the MLD in March exceeds $1000 \mathrm{~m}$ in at least 100 integration years). The multidecadal variability of the different indices is, however, rather similar, with correlation coefficients exceeding 0.9 (not shown). We are therefore confident that our results do not critically depend on the definition of the SDWI.

Apart from the subpolar deep convection, deep convection is found in the Nordic Seas (Fig. 2). Also in the Nordic Seas, mean location and depth of the deep water formation vary among the different control simulations. As mentioned 

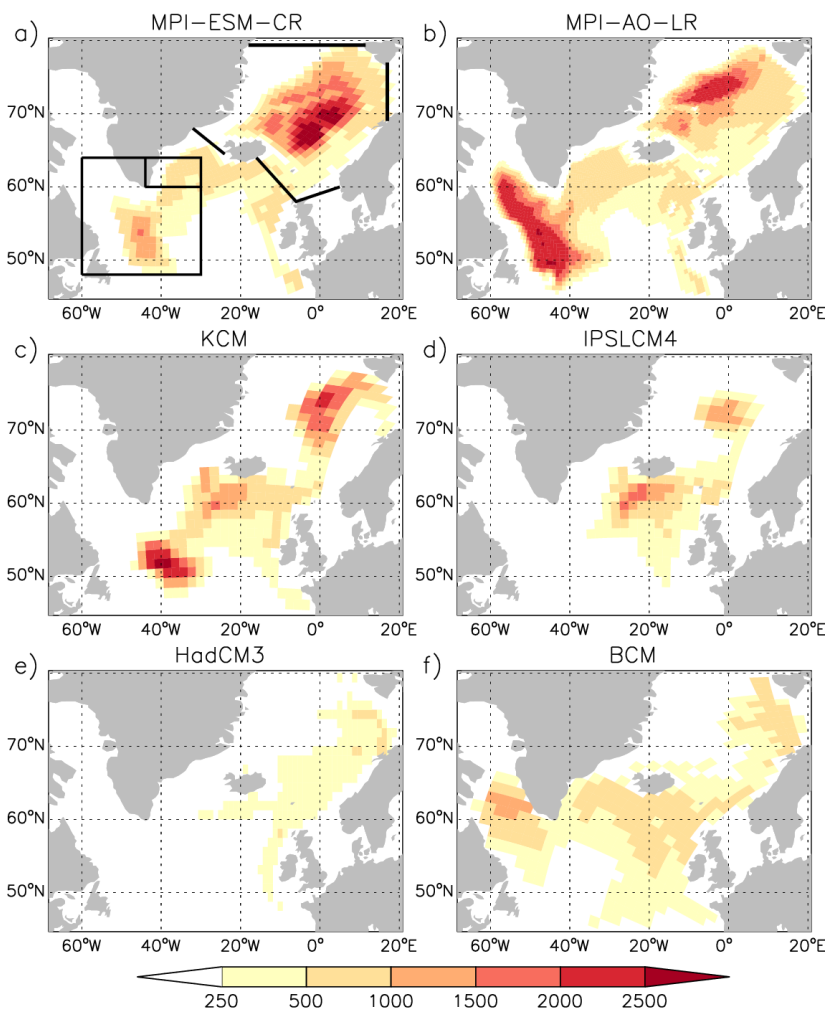

Fig. 2. Mean mixed layer depth in March (in metres) in the control simulation with (a) MPI-ESM-CR, (b) MPI-AO-LR, (c) KCM, (d) IPSLCM4, (e) HadCM3 and (f) BCM. The boxes in (a) indicate the area where in the sensitivity experiments temperature and salinity are relaxed towards climatological values.

earlier, we do not directly consider deep water formation in the Nordic Seas, but rather use the overflow transports across the GSR. The overflow transports through the Denmark Strait (DSO) and across the Iceland-Scotland Ridge (ISRO) are defined based on density (and depth) criteria according to the respective water mass properties at the GSR in the different models. In general, the total transport out of the Nordic Seas with a density threshold of $\sigma>27.8 \mathrm{~kg} \mathrm{~m}^{-3}$ is used. A description of the criteria used in the different models is given in Appendix B.

Mean simulated values of DSO and ISRO lie between about 2 and $4 \mathrm{~Sv}$ (Table 2), in reasonable agreement with observational estimates (e.g. Hansen et al., 2008). An exception is the DSO in KCM, IPSLCM4 and HadCM3, where mean values of the order of $10 \mathrm{~Sv}$ are found. The reason for the unrealistically large DSO in the three models is not clear, but we note that all models have realistic sill depths at the GSR. In contrast to observations, where an overflow transport of about $1 \mathrm{~Sv}$ is found between Iceland and the Faroe Islands (e.g. Østerhus et al., 2008), the simulated ISRO is (mostly) restricted to the Faroe-Shetland Channel in all models. South of the Iceland-Scotland Ridge, one major bias in all models except for KCM is that (a large part of)
Table 2. Mean value of the overflow transport through the Denmark Strait (DSO) and across the Iceland-Scotland Ridge (ISRO) in the different control simulations.

\begin{tabular}{lrr}
\hline Model & Mean DSO & Mean ISRO \\
\hline MPI-ESM-CR & $2.8 \mathrm{~Sv}$ & $2.3 \mathrm{~Sv}$ \\
MPI-AO-LR & $2.8 \mathrm{~Sv}$ & $3.5 \mathrm{~Sv}$ \\
KCM & $12.7 \mathrm{~Sv}$ & $2.3 \mathrm{~Sv}$ \\
IPSLCM4 & $10.8 \mathrm{~Sv}$ & $2.4 \mathrm{~Sv}$ \\
HadCM3 & $8.0 \mathrm{~Sv}$ & $3.4 \mathrm{~Sv}$ \\
BCM & $1.9 \mathrm{~Sv}$ & $3.8 \mathrm{~Sv}$ \\
\hline
\end{tabular}

the Iceland-Scotland overflow water spreads southward in the eastern part of the North Atlantic Basin (e.g. Langehaug et al., 2012a; their Fig. 5), rather than flowing around the Reykjanes Ridge (through fracture zones in the Mid-Atlantic Ridge) and joining the Denmark Strait overflow water and the deep western boundary current.

\section{Analysis of multimodel control simulations}

In this section, we present the results from a correlation analysis between the maximum AMOC strength at different latitudes in the North Atlantic and respectively SDWI, DSO and ISRO in the multimodel control simulations.

Maximum correlation coefficients between SDWI and AMOC strength on multidecadal timescales (Fig. 3) are found at $45^{\circ} \mathrm{N}$ in all models, with the exception of MPIESM-CR, where they are located at about $40^{\circ} \mathrm{N}$. In IPSLCM4, similarly high correlation coefficients are found between about 45 and $55^{\circ} \mathrm{N}$. Maximum correlation coefficients amount to $0.85-0.9$, with the exception of HadCM3, where they reach a value of only 0.55 . We note that HadCM3 also exhibits substantially weaker regression coefficients (per standard deviation of SDWI) compared to the other models (not shown). Maximum regression coefficients amount to $0.35 \mathrm{~Sv}$ (per standard deviation of SDWI) in HadCM3 compared to $0.5-0.8 \mathrm{~Sv}$ (per standard deviation of SDWI) in the other models. The negative correlation coefficients alternating with the positive ones (e.g. Fig. 3b) indicate the dominant periodicity of AMOC variability and are not further discussed here.

Significant correlation coefficients between SDWI and AMOC strength are found, except for MPI-ESM-CR, at all latitudes in the North Atlantic (latitude range 0 to $15^{\circ} \mathrm{N}$ not shown). In MPI-ESM-CR, correlation coefficients at zero lag or with the AMOC strength lagging are significant only between about 25 and $50^{\circ} \mathrm{N}$. The reason for this difference is not clear, but horizontal resolution might play a role in the MPI model simulations. In MPI-AO-LR, where a higher-resolution grid configuration is used compared to MPI-ESM-CR, significant correlation coefficients extend to higher mid-latitudes as well as into the subtropics (Fig. 3a, 

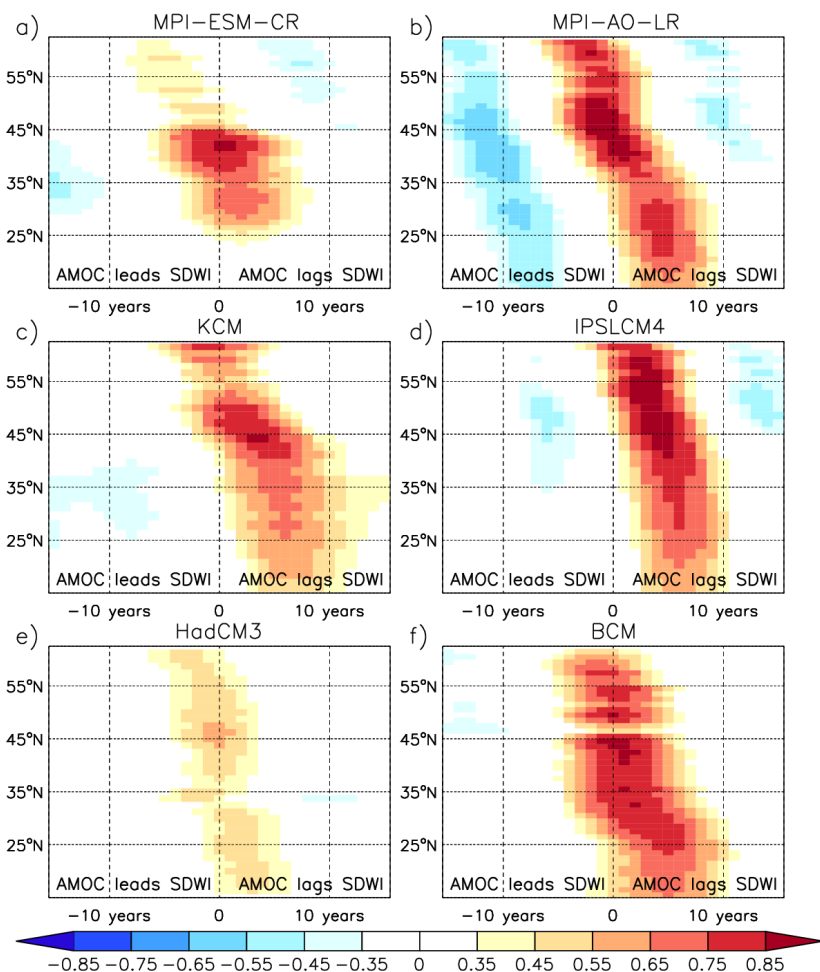

Fig. 3. Lag correlation coefficients between the bandpass-filtered (15-80 years) subpolar deep water formation index (SDWI) and maximum Atlantic meridional overturning streamfunction at different latitudes in the North Atlantic in the control simulation with (a) MPI-ESM-CR (depth level $1020 \mathrm{~m}$ ), (b) MPI-AO-LR (depth level $1020 \mathrm{~m}$ ), (c) KCM (depth level $870 \mathrm{~m}$ ), (d) IPSLCM4 (depth level $1210 \mathrm{~m}$ ), (e) HadCM3 (depth level $800 \mathrm{~m}$ ) and (f) BCM (depth level $1000 \mathrm{~m}$ ). Only correlation coefficients significant at the $95 \%$ level for a two-tailed $t$ test (taking into account both length and decorrelation timescale of the SDWI and the overall maximum strength of the Atlantic meridional overturning streamfunction) are plotted (significance level: 0.31 for MPI-AO-LR, 0.27 for BCM and 0.23 for the other models). Positive (negative) lags indicate that the SDWI is leading (lagging).

b). In HadCM3, correlation coefficients are relatively low compared to the other models (partly except for MPI-ESMCR) at all latitudes. The same is true, if regression coefficients (per standard deviation of SDWI) rather than correlation coefficients are considered (not shown). We speculate that this is due to the fact that HadCM3 exhibits a rather shallow subpolar deep water formation (Fig. 2e).

Maximum correlation coefficients between DSO and AMOC strength on multidecadal timescales (Fig. 4) are found at about $60^{\circ} \mathrm{N}$ in all models. They amount to $0.85-0.9$, with the exception of BCM, where they reach a value of 0.75 . In addition, strong correlation coefficients are found at about $45^{\circ} \mathrm{N}$ in MPI-AO-LR and KCM as well as for all subpolar latitudes in IPSLCM4. We note that KCM and IPSLCM4 exhibit a much larger variability of the DSO than the other
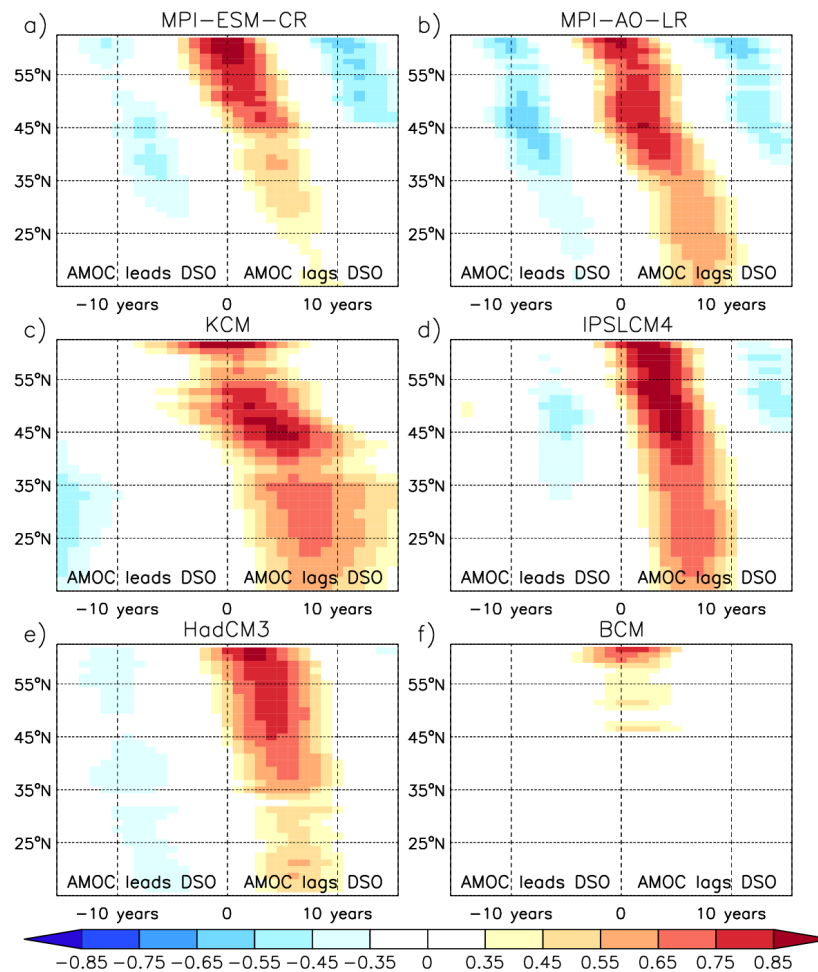

Fig. 4. Same as Fig. 3, but for the correlation between the Denmark Strait overflow transport (DSO) and Atlantic meridional overturning streamfunction.

models (standard deviation of the order of $1.5 \mathrm{~Sv}$ compared to less than $0.5 \mathrm{~Sv}$ in the other models).

Significant correlation coefficients between DSO and AMOC strength are found at all latitudes in the North Atlantic (latitude range $0-15^{\circ} \mathrm{N}$ not shown), with the exception of BCM. In the latter, significant correlation coefficients are only found close to the GSR. We note that BCM is the only model with an isopycnic vertical coordinate. In another multimodel study using partly the same climate models as here, Swingedouw et al. (2013) underline the limited grid resolution of this model in the Denmark Strait region. In MPI-ESM-CR, correlation coefficients south of about $30^{\circ} \mathrm{N}$ are barely significant. As mentioned above, horizontal resolution might play a role in the MPI model simulations, as MPI-AO-LR, where a higher-resolution grid configuration is used compared to MPI-ESM-CR, shows higher correlation coefficients south of about $45^{\circ} \mathrm{N}$ (Fig. $4 \mathrm{a}, \mathrm{b}$ ). In KCM and IPSLCM4, correlation coefficients between AMOC strength and respectively SDWI and DSO are rather similar (Fig. 3c, d compared to Fig. 4c, d). In both models, however, SDWI and DSO are highly correlated with each other (correlation coefficient of about 0.8 ). We note that this could be due to a specific feature of the oceanic component as these two coupled climate models use the same one. 
Regarding the correlation between ISRO and AMOC strength on multidecadal timescales (Fig. 5), correlation coefficients are generally rather low compared to the correlation between DSO and AMOC strength. The same is true if regression coefficients (per standard deviation of ISRO and DSO respectively) rather than correlation coefficients are considered (not shown). In IPSLCM4, HadCM3 and $\mathrm{BCM}$, an out-of-phase relation of DSO and ISRO is found on multidecadal timescales. Such an out-of-phase relation on timescales of 3-10 years is described by Serra et al. (2010), based on an ocean-only simulation with the MITgcm (Massachusetts Institute of Technology general circulation model) model forced with atmospheric reanalysis fields. Consistent with the out-of-phase relation of the two overflow branches, positive correlation coefficients are found when the AMOC strength leads the ISRO by a few years in IPSLCM4 and HadCM3. BCM shows almost no significant correlation coefficients between ISRO and AMOC strength.

In MPI-ESM-CR and MPI-AO-LR, significant correlation coefficients between ISRO and AMOC strength are found for the subpolar latitudes. In MPI-ESM-CR, correlation coefficients lie between 0.5 and 0.7 , while in MPI-AO-LR they are just above the significance level. KCM is the only model, where significant correlation coefficients are found at all latitudes between 10 and $60^{\circ} \mathrm{N}$ (latitude range $10-15^{\circ} \mathrm{N}$ not shown), with correlation coefficients of 0.4-0.6. We note that the simulated influence of the ISRO on the multidecadal AMOC variability might, however, be underestimated, as the models (except for KCM) do not realistically simulate the flow path of the Iceland-Scotland overflow water south of the Iceland-Scotland Ridge.

The latitude where the maximum correlation coefficients between SDWI and AMOC strength are found (about $45^{\circ} \mathrm{N}$ ), coincides, with the exception of HadCM3, with the latitude where the maximum standard deviation of multidecadal AMOC variability is located. The maximum standard deviation is of the order of $0.5-1 \mathrm{~Sv}$ and is, with the exception of HadCM3, located at about $45^{\circ} \mathrm{N}$ at a depth of $1500 \mathrm{~m}$ (Fig. 6), below the depth at which the overall maximum AMOC strength in the North Atlantic is found. In HadCM3, the maximum standard deviation of multidecadal AMOC variability is found at $60^{\circ} \mathrm{N}$, coinciding with the latitude where the maximum correlation coefficients between DSO and AMOC strength are found. We note that HadCM3 shows relatively low correlation coefficients between SDWI and AMOC strength compared to the other models (except for partly MPI-ESM-CR, Fig. 3). Whether the multidecadal AMOC variability at 45 and $60^{\circ} \mathrm{N}$ is, to a large extent, indeed driven by variations in subpolar deep water formation and Denmark Strait overflow respectively, can, however, not definitely be determined from the statistical analysis presented in this section.

Based on the correlation analysis for the individual models, we have deduced the multimodel average of the multidecadal AMOC variance explained by SDWI and DSO
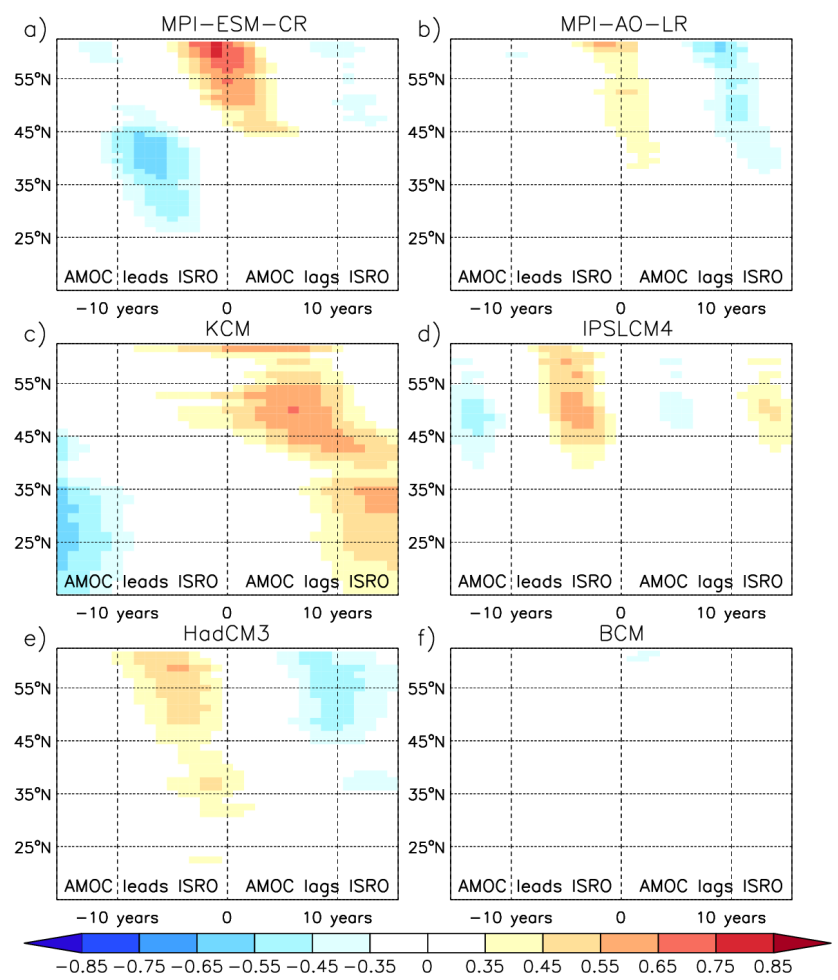

Fig. 5. Same as Fig. 3, but for the correlation between overflow transport across the Iceland-Scotland Ridge (ISRO) and Atlantic meridional overturning streamfunction.

respectively (Table 3). The ISRO explains substantially less variance than the DSO. Furthermore, in some models (IPSLCM4, HadCM3 and BCM), it is out of phase with the AMOC variability. Thus we do not comment further its influence here. At $45^{\circ} \mathrm{N}$, where the maximum standard deviation of multidecadal AMOC variability is found, the variance explained by SDWI and DSO amounts, on multimodel average, to 68 and $57 \%$ respectively. The sum of the explained variances by SDWI and DSO amounts to more than $100 \%$, indicating that these two processes are not completely independent from each other. At the more classical latitude of $30^{\circ} \mathrm{N}$, the variance explained by SDWI and DSO amounts, on multimodel average, to 50 and $30 \%$ respectively, suggesting that the influence of both subpolar deep water formation and Nordic Seas overflow on the multidecadal AMOC variability is weaker at this latitude.

One possible explanation for the lower variance explained by SDWI and DSO at 30 compared to $45^{\circ} \mathrm{N}$ is the local influence of varying Ekman transport. Time series of the bandpass-filtered (15-80 years) Ekman transport in MPIESM-CR, where the variance explained by SDWI and DSO is similar to the multimodel average (Table 3), show a standard deviation of $0.18 \mathrm{~Sv}$ at $45^{\circ} \mathrm{N}$, compared to a standard deviation exceeding $0.6 \mathrm{~Sv}$ for multidecadal AMOC time series at the same latitude (Fig. 6a). At $30^{\circ} \mathrm{N}$, however, 
Table 3. Summary of the maximum variance of the bandpass-filtered (15-80 years) Atlantic meridional overturning streamfunction at 45 and $30^{\circ} \mathrm{N}$ explained SDWI and DSO in the different control simulations, deduced from Figs. 3 and 4 using (correlation coefficient) ${ }^{2}$.

\begin{tabular}{lrrrr}
\hline Model & SDWI - AMOC $45^{\circ} \mathrm{N}$ & DSO - AMOC $45^{\circ} \mathrm{N}$ & SDWI - AMOC 30 N & DSO - AMOC 30 N \\
\hline MPI-ESM-CR & $72 \%$ & $49 \%$ & $49 \%$ & $25 \%$ \\
MPI-AO-LR & $81 \%$ & $72 \%$ & $64 \%$ & $36 \%$ \\
KCM & $72 \%$ & $72 \%$ & $42 \%$ & $49 \%$ \\
IPSLCM4 & $81 \%$ & $72 \%$ & $56 \%$ & $49 \%$ \\
HadCM3 & $30 \%$ & $56 \%$ & $25 \%$ & $20 \%$ \\
BCM & $72 \%$ & $20 \%$ & $64 \%$ & not significant \\
\hline Multimodel average & $68 \%$ & $57 \%$ & $50 \%$ & $30 \%$ \\
\hline
\end{tabular}
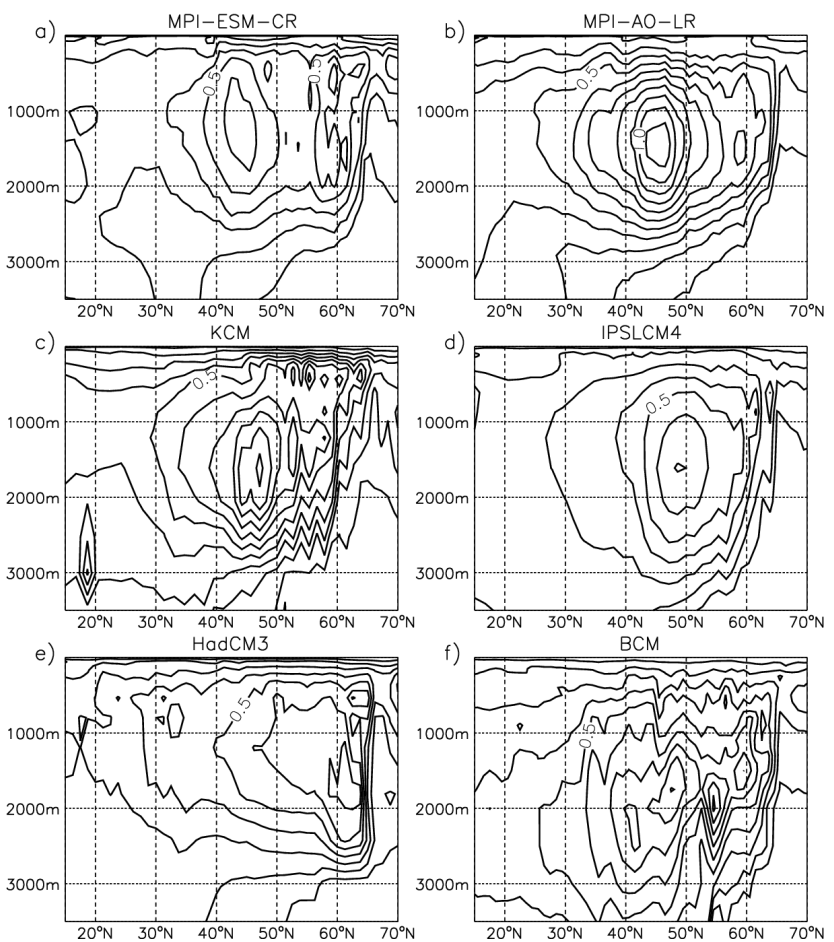

Fig. 6. Standard deviation of the bandpass-filtered (15-80 years) Atlantic meridional overturning streamfunction (in $\mathrm{Sv}$ ) in the control simulation with (a) MPI-ESM-CR, (b) MPI-AO-LR, (c) KCM, (d) IPSLCM4, (e) HadCM3 and (f) BCM. Contour interval is $0.1 \mathrm{~Sv}$, starting from $0.1 \mathrm{~Sv}$.

a standard deviation of $0.25 \mathrm{~Sv}$ is found for the bandpassfiltered Ekman transport, compared to a standard deviation of less than $0.4 \mathrm{~Sv}$ for the multidecadal AMOC.

\section{Sensitivity experiments with MPI-ESM-CR}

\subsection{Design of sensitivity experiments}

The statistical analysis of the multimodel control simulations presented in the previous section could be biased by the fact that subpolar deep water formation and Nordic Seas overflows are somehow coupled. In order to more directly estimate the respective role of these two processes, we have performed two 1000 year-long sensitivity experiments with the MPI-ESM-CR model set-up (Table 1) by suppressing the variations in either subpolar deep water formation (in the following referred to as SDW experiment) or Nordic Seas overflows (in the following referred to as overflow experiment). Initial conditions are the same as for the control simulation.

In the SDW experiment, we relax temperature and salinity in the western subpolar region $\left(60-30^{\circ} \mathrm{W}, 48-64^{\circ} \mathrm{N}\right.$; see box in Fig. 2a) towards monthly climatological values obtained from the control simulation. The relaxation timescale is one day. The region where relaxation is applied corresponds to the subpolar deep water formation site. We also include the Irminger Sea in this area, as previous modelling studies suggest a significant correlation between convective mixing in the Irminger Sea and decadal AMOC variability (e.g. Bentsen et al., 2004; Ba et al., 2013). Ba et al. (2014) show that this is true also for the MPI-ESM-CR control simulation. In the Irminger Sea region $\left(45-30^{\circ} \mathrm{W}, 60-64^{\circ} \mathrm{N}\right.$; see small box in Fig. 2a), where the convection is relatively shallow, relaxation is applied down to a depth of $500 \mathrm{~m}$, otherwise down to a depth of $900 \mathrm{~m}$. The deeper levels as well as the upper four levels (approximately the upper $40 \mathrm{~m}$ of the water column) are excluded from relaxation to keep the variability of the overflow water masses as well as the coupling between ocean and atmosphere unaffected.

In the overflow experiment, we relax temperature and salinity in the Nordic Seas and along the GSR (boundaries indicated by the black lines in Fig. 2a) towards monthly climatological values obtained from the control simulation. The relaxation timescale is 1 day. The relaxation is applied in the entire water column, excluding the upper four levels to keep the coupling between ocean and atmosphere unaffected. The relaxation of Nordic Seas temperature and salinity towards climatological values also leads to a density of the overflow water masses at the GSR, which is almost constant with time.

Since temperature and salinity are relaxed towards climatological mean values taken from the control simulation, the simulated mean state in the North Atlantic in the two sensitivity experiments remains approximately unchanged compared to the simulated mean state in the control simulation (as described in Sect. 2). SDWI, DSO and ISRO in the 

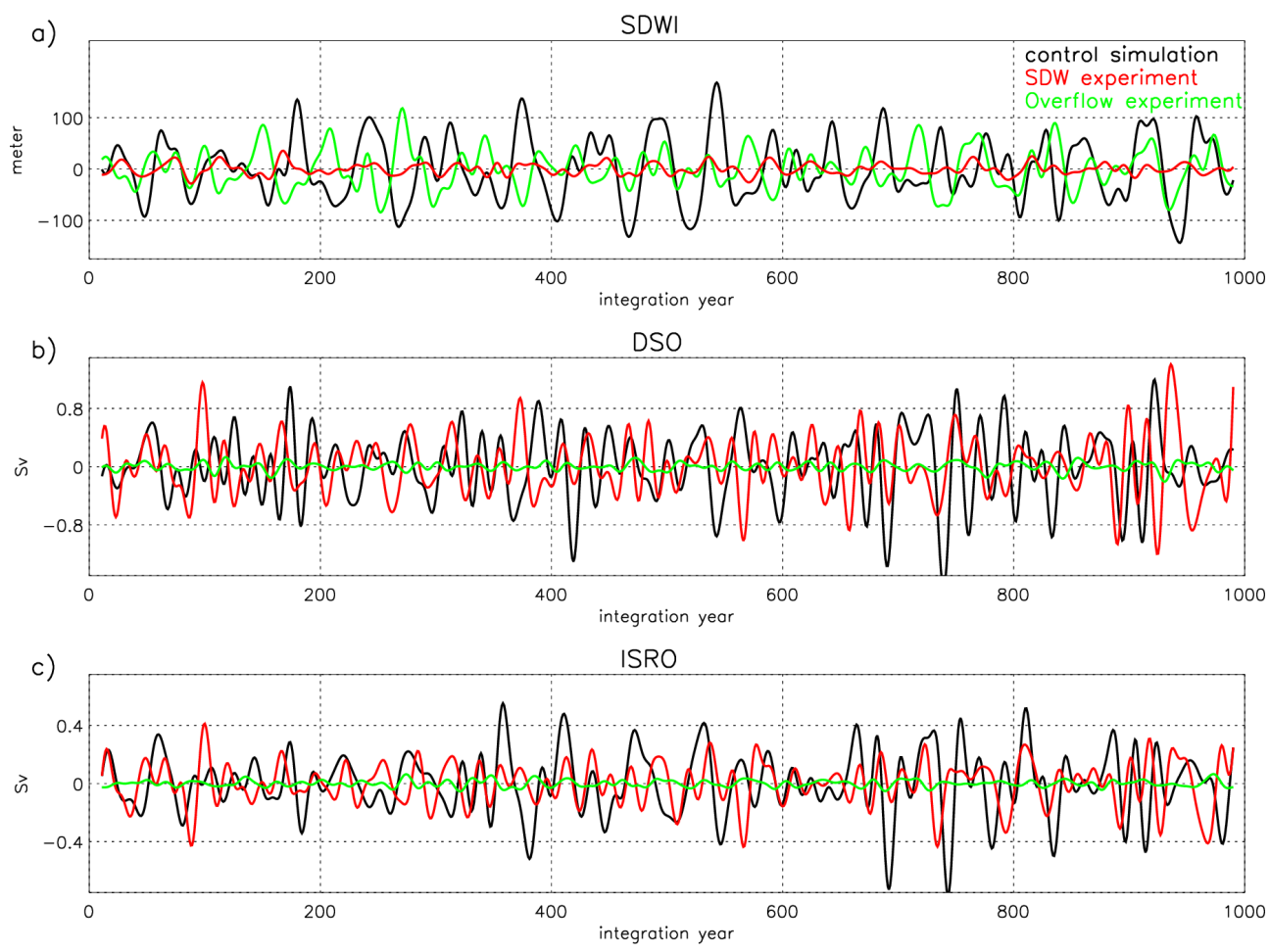

Fig. 7. Anomalous bandpass-filtered (15-80 years) (a) SDWI (in m), (b) DSO (in Sv) and (c) ISRO (in Sv) in the control simulation (black lines), the SDW experiment (red lines) and the overflow experiment (green lines) with MPI-ESM-CR. The respective standard deviations are given in the table. Numbers in brackets in the table give the reduction (in \%) in the standard deviation in the respective sensitivity experiment compared to the control simulation.

sensitivity experiments are defined in the same way as described in Sect. 2 for the control simulation.

\subsection{Results of sensitivity experiments}

In the SDW experiment, the multidecadal variability of the SDWI is reduced by $82 \%$ compared to the control simulation (Fig. 7a and table within). A reduction of $29 \%$ is, however, also found in the multidecadal variability of the ISRO (Fig. 7c and table). One possible explanation of this phenomenon is as follows: reduced AMOC variability (due to reduced subpolar deep water formation variability) leads to reduced SST (sea surface temperature) variability in the eastern part of the Nordic Seas, as indicated by the correlation pattern between the maximum AMOC strength and North Atlantic SST in the control simulation (not shown). The variability of the overflow across the Iceland-Scotland Ridge in ocean-only and coupled simulations using the ocean component of MPI-ESM-CR is significantly correlated with the SST variability in the eastern part of the Nordic Seas and related changes in surface density, convective mixing and sea surface height (e.g. Olsen et al., 2008).

In the overflow experiment, the multidecadal variability of both DSO and ISRO is reduced by about $90 \%$ compared to the control simulation (Fig. 7b, c and table). A reduction of
$38 \%$ is, however, also found in the multidecadal variability of the SDWI (Fig. 7a and table). This might be due to reduced AMOC variability (due to reduced overflow variability) inducing reduced subpolar deep water formation variability caused by ocean internal modes such as the one described in Zhu and Jungclaus (2008). Variations in Nordic Seas overflow and subpolar deep water formation might thus not be completely independent, at least in this model. We note, however, that in the control simulation, SDWI and DSO/ISRO are not significantly correlated with each other. Another possible explanation is that the relaxation of Nordic Seas temperature and salinity towards climatological values reduces, via advection along the East Greenland Current, upper-ocean temperature and salinity variability in the subpolar region, especially in the Irminger Sea, and consequently probably affects variability of subpolar deep water formation.

Regarding the multidecadal AMOC variability, the amplitude of variability is reduced in the sensitivity experiments compared to the control simulation (Fig. 8). We quantify the reduction in the standard deviation of the AMOC strength in the sensitivity experiments compared to the control simulation as follows: $100 \cdot[1-$ $\left.\left(\sigma\left(\mathrm{AMOC}_{\text {sensitivity experiment }}\right) / \sigma\left(\mathrm{AMOC}_{\text {control simulation }}\right)\right)\right]$. Note that positive values correspond to a reduction in the 

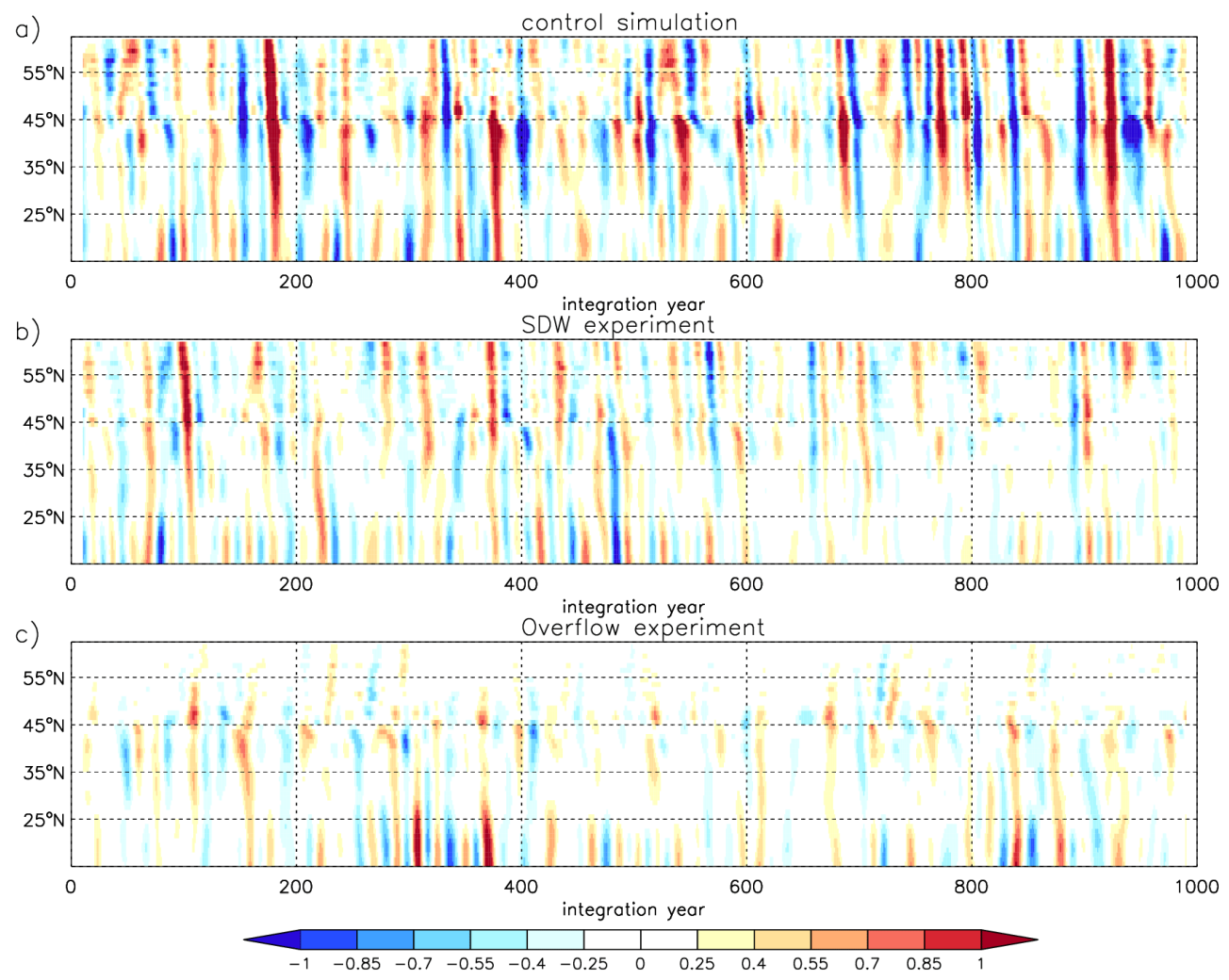

Fig. 8. Anomalous bandpass-filtered (15-80 years) maximum Atlantic meridional overturning streamfunction (in $\mathrm{Sv}$ ) at different latitudes in the North Atlantic (depth level $1020 \mathrm{~m}$ ) in (a) the control simulation, (b) the SDW experiment and (c) the overflow experiment with MPI-ESM-CR.

standard deviation of the AMOC strength in the sensitivity experiments.

In the SDW experiment (Fig. 9a), the maximum reduction in the standard deviation of multidecadal AMOC variability amounts to about $60 \%$ and is found at about $45^{\circ} \mathrm{N}$. This latitude is similar to the latitude where the maximum correlation coefficients between SDWI and AMOC strength are found in the control simulation (Fig. 3a). At $30^{\circ} \mathrm{N}$, the reduction in the standard deviation of multidecadal AMOC variability in the SDW experiment amounts to about $50 \%$.

In the overflow experiment (Fig. 9b), the maximum reduction in the standard deviation of multidecadal AMOC variability amounts to about $80 \%$ and is found at 55 to $60^{\circ} \mathrm{N}$, again similarly to the latitude of the maximum correlation coefficients between both DSO and AMOC strength and ISRO and AMOC strength in the control simulation (Figs. 4a, 5a). At $45^{\circ} \mathrm{N}$ and south of this latitude, the reduction in the standard deviation of multidecadal AMOC variability is similar to what is found in the SDW experiment. We remind the reader, however, that in the overflow experiment also the variability of the SDWI is reduced by almost $40 \%$ (Fig. 7a and table). It is interesting to note that the maximum reduction in the standard deviation in the overflow experiment is found below the depth at which the overall maximum AMOC strength in the North Atlantic is located (solid line in Fig. 9b). This indicates that the overflow water masses, as in the real ocean, contribute to the lower North Atlantic Deep Water.

In summary, we conclude from the sensitivity experiments that the multidecadal AMOC variability north of about $50^{\circ} \mathrm{N}$ is mainly related to variations in Nordic Seas overflows. At $45^{\circ} \mathrm{N}$ and south of this latitude, variations in both subpolar deep water formation and Nordic Seas overflows contribute to the multidecadal AMOC variability, with neither of the processes being very dominant compared to the other.

\section{Discussion and conclusions}

In this study, we have analysed long control simulations with five coupled climate models as well as sensitivity experiments performed with one of the models in order to add to the discussion in the literature about the respective role of variations in subpolar deep water formation and Nordic Seas overflows for the multidecadal AMOC variability.

Regarding the multimodel control simulations (Table 3), the multidecadal AMOC variance explained by subpolar deep water formation is higher than or of similar order as the one explained by the Denmark Strait overflow. This is true for all models at both $45^{\circ} \mathrm{N}$, where the maximum standard 

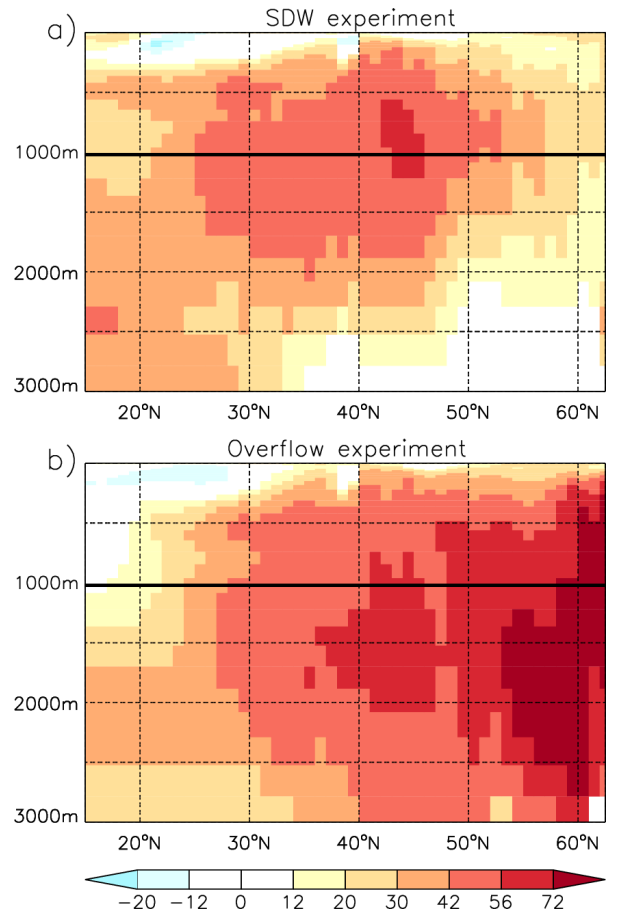

Fig. 9. Change (in \%, for definition see text) in the standard deviation of the bandpass-filtered (15-80 years) Atlantic meridional overturning streamfunction in (a) the SDW experiment and (b) the overflow experiment compared to the control simulation with MPIESM-CR. Note that positive (negative) values correspond to a reduction (increase) in the standard deviation in the sensitivity experiments. The colour scale is chosen to match the explained variance, i.e. (correlation coefficient) ${ }^{2}$, in Figs. 3-5. The depth level presented in Figs. $3-5$ is indicated by the solid line.

deviation of multidecadal AMOC variability is found, and at the more classical latitude of $30^{\circ} \mathrm{N}$, with the exception of $45^{\circ} \mathrm{N}$ in HadCM3. In the latter, the Denmark Strait overflow seems to have a relatively strong influence on the AMOC variability. We note that HadCM3 indeed shows a rather shallow subpolar deep water formation compared to the other models (Fig. 2). We also note that HadCM3 is the only model, in which the maximum standard deviation of multidecadal AMOC variability is found at $60^{\circ} \mathrm{N}$, rather than at $45^{\circ} \mathrm{N}$. The multidecadal AMOC variance explained by the Denmark Strait overflow is, for all models, substantially larger than the one explained by the overflow across the Iceland-Scotland Ridge. The latter might, however, be underestimated, as the models in general do not realistically simulate the flow path of the Iceland-Scotland overflow water south of the Iceland-Scotland Ridge.

The respective role of subpolar deep water formation and Nordic Seas overflows on the multidecadal AMOC variability suggested from the control simulations is supported by the sensitivity experiments. The latter indicate that the maximum influence of Nordic Seas overflow variations is found below the depth at which the overall maximum AMOC strength in the North Atlantic is located. However, the conclusions of our study do not change if the correlation analysis based on the multimodel control simulations is repeated for depth levels located in the lower branch of the AMOC.

Our results are in contrast with previous studies, which find the major influence from the Denmark Strait overflow (e.g. Köhl and Stammer, 2008), and rather in line with the ones suggesting a larger influence of subpolar deep water formation on the AMOC variability (e.g. Bailey et al., 2005; Latif et al., 2006; Böning et al., 2006). We note, however, that in only one of the models (BCM) the multidecadal AMOC variance explained by subpolar deep water formation is substantially larger than the one explained by the Denmark Strait overflow.

In some previous modelling studies (e.g. Jungclaus et al., 2005; Msadek and Frankignoul, 2009; Escudier et al., 2013), the AMOC variability was found not to be strongly related to convective mixing in the Nordic Seas. Variations in Nordic Seas convection, however, do not necessarily match with variations in the overflows across the GSR, since the source waters of the overflow water masses at the GSR are relatively complex (e.g. Tanhua et al., 2008; Våge et al., 2013). Our study suggests that the Denmark Strait overflow, though its influence is, on multimodel average, smaller than that of subpolar deep water formation, still explains a substantial part of multidecadal AMOC variance. At the classical latitude of $30^{\circ} \mathrm{N}$, variations in Denmark Strait overflow and subpolar deep water formation explain, on multimodel average, about one-third and half of multidecadal AMOC variance respectively.

However, AMOC variations related to either subpolar deep water formation or Nordic Seas overflow variability will, through varying northward heat and fresh water transport, influence the surface density in the northern North Atlantic and might consequently affect the other of these two processes. The conclusions discussed above about the respective role of variations in subpolar deep water formation and Nordic Seas overflows for multidecadal AMOC variability might therefore be biased by the fact that these two processes are somehow coupled. If the respective role of variations in subpolar deep water formation is overestimated (due to influence by Nordic Seas overflows), then the multidecadal AMOC variance explained by subpolar deep water formation and Denmark Strait overflow will be of comparable order. If, on the other hand, the respective role of variations in Denmark Strait overflow is overestimated (due to influence by subpolar deep water formation), then only a minor part of multidecadal AMOC variance will be explained by the Denmark Strait overflow. We note, however, that in MPI-ESM-CR, which is the only model (apart from HadCM3) where subpolar deep water formation index and Denmark Strait overflow are not significantly correlated in the control integration, the respective role of these two processes for multidecadal AMOC variations is similar to the conclusions drawn from the presented analysis (Table 3). 
One caveat of our study is the coarse horizontal and vertical resolution of the model grid configurations used. The resolution is non-eddy permitting, with, to some degree, the exception of MPI-AO-LR. Such coarse-resolution grid configurations allow the performance of sufficiently long simulations to ensure robust results on multidecadal timescales but, however, lead to model biases, which might affect the realism of the discussed influence of subpolar deep water formation and Nordic Seas overflows on multidecadal AMOC variations. Apart from the unrealistic flow path of the IcelandScotland overflow water mentioned above, one major model bias is the location of the subpolar deep water formation site, which also differs among models (Fig. 2). Only in MPIAO-LR, where a higher-resolution grid configuration is used compared to the other models, and in BCM, deep water formation is, as in the real ocean, found in the central Labrador Sea. Another caveat of the model simulations used here is the generally biased representation of the overflow water masses in $z$ coordinate models (e.g. Willebrand et al., 2001; Danabasoglu et al., 2010; Yeager and Danabasoglu, 2012), resulting in a too shallow meridional overturning cell. Furthermore, the structure of the meridional overturning cell differs among the models, both with respect to mean state and multidecadal variability (Figs. 1, 6). Regarding the latter, also the dominant periodicity varies among models. The largest value of the maximum AMOC strength as well as the largest variability are found in MPI-AO-LR, where a higher-resolution grid configuration is used compared to the other models.

Currently, millennial-scale simulations with eddypermitting or even eddy-resolving grid configurations are not available. The differences among models as well as their biases, however, underline the importance of understanding multidecadal AMOC variability based on simulations with high-resolution grid configurations in the future.

Acknowledgements. This work was supported by the European Community's 7th framework programme (FP7/2007-2013) under grant agreement no. GA212643 (THOR: Thermohaline circulation - at risk?, 2008-2012). K. Lohmann also received funding through the Cluster of Excellence "CLISAP", funded by the German Science Foundation (DFG). D. Matei was supported by the Federal Ministry for Education and Research (BMBF) NORTH ATLANTIC and RACE projects. The authors wish to thank Michael Botzet and Helmuth Haak for their help with setting up the sensitivity experiments, Manfred Bersch for his help with the definition of the subpolar deep water formation index and Xiuhua Zhu for a critical review of the manuscript prior to submission. Helpful comments, which further improved the manuscript, by Anders Levermann and two anonymous reviewers are greatly acknowledged. The MPI-ESM-CR and MPI-AO-LR simulations were conducted at the German Climate Computing Center (DKRZ). This study is a contribution to the Centre for Climate Dynamics at the Bjerknes Centre.

The service charges for this open access publication have been covered by the Max Planck Society.

Edited by: S. Josey

\section{References}

Ba, J., Keenlyside, N., Park, W., Latif, M., Hawkins, E., and Ding, H.: A mechanism for Atlantic multidecadal variability in the Kiel Climate Model, Clim. Dynam., 41, 2133-2144, doi:10.1007/s00382-012-1633-4, 2013.

Ba, J., Keenlyside, N., Latif, M., Park, W., Ding, H., Lohmann, K., Mignot, J., Menary, M., Otterå, O. H., Wouters, B., Salas, D., Oka, A., Belluci A., and Volodin, E.: A multi-model comparison for Atlantic multidecadal variability, Clim. Dynam., online first, doi:10.1007/s00382-014-2056-1, 2014.

Bailey, D., Rhines P., and Häkkinen, S.: Formation and pathways of North Atlantic Deep Water in a coupled ice-ocean model of the Arctic-North Atlantic Oceans, Clim. Dynam., 25, 497-516, 2005.

Bentsen, M., Drange, H., Furevik, T., and Zhou, T.: Simulated variability of the Atlantic meridional overturning circulation, Clim. Dynam., 22, 701-720, 2004.

Biastoch, A., Böning, C., Getzlaff, J., Molines, J.-M., and Madec, G.: Causes of interannual-decadal variability in the meridional overturning circulation of the midlatitude North Atlantic Ocean, J. Climate, 21, 6599-6615, 2008.

Böning, C., Scheinert, M., Dengg, J., Biastoch, A., and Funk, A.: Decadal variability of subpolar gyre transport and its reverberation in the North Atlantic overturning, Geophys. Res. Lett., 33, L21S01, doi:10.1029/2006GL026906, 2006.

Cunningham, S., Kanzow, T., Rayner, D., Baringer, M. O., Johns, W. E., Marotzke, J., Longworth, H. R., Grant, E. M., Hirschi, J. J.-M., Beal, L. M., Meinen, C. S., and Bryden, H. L.: Temporal Variability of the Atlantic Meridional Overturning Circulation at 26.5 ${ }^{\circ}$ N, Science, 317, 935-938, 2007.

Danabasoglu, G., Large, W. G., and Briegleb, B. P.: Climate impacts of parameterized Nordic Sea overflows, J. Geophys. Res., 115, C11005, doi:10.1029/2010JC006243, 2010.

Danabasoglu, G., Yeager, S. G., Kwon, Y.-O., Tribbia, J. J., Phillips, A. S., and Hurrell, J. W.: Variability of the Atlantic meridional overturning circulation in CCSM4, J. Climate, 25, 5153-5172, 2012.

Escudier, R., Mignot, J., and Swingedouw, D.: A 20-yrs coupled ocean-sea ice-atmosphere variability mode in the North Atlantic in an AOGCM, Clim. Dynam., 40, 619-636, doi:10.1007/s00382-012-1402-4, 2013.

Fischer, N.: Holocene and Eemian climate variability, $\mathrm{PhD}$ thesis, Berichte zur Erdsystemforschung No. 91, Max Planck Institute for Meteorology, Hamburg, Germany, 106 pp., 2011.

Furevik, T., Bentsen, M., Drange, H., Kindem, I., Kvamstø, N., and Sorteberg, A.: Description and evaluation of the Bergen climate model: ARPEGE coupled with MICOM, Clim. Dynam., 21, 27$51,2003$.

Gastineau, G. and Frankignoul, C.: Cold-season atmospheric response to the natural variability of the Atlantic meridional overturning circulation, Clim. Dynam., 39, 37-57, 2012.

Gordon, C., Cooper, C., Senior, C., Banks, H., Gregory, J., Johns, T., Mitchell, J., and Wood, R.: The simulation of SST, sea ice extents and ocean heat transports in a version of the Hadley Centre coupled model without flux adjustments, Clim. Dynam., 16, 147-168, 2000.

Hall, M. and Bryden, H.: Direct estimates and mechanisms of ocean heat transport, Deep Sea Res.-Pt. A, 29, 339-359, 1982. 
Hansen, B., Østerhus, S., Turrell, B., Jónsson, S., Valdimarsson, H., Hátún, H., and Olsen, S.: The inflow of Atlantic water, heat, and salt to the Nordic Seas across the Greenland-Scotland Ridge, in: Arctic-Subarctic Ocean Fluxes, edited by: Dickson, R., Meincke, J., and Rhines, P., Springer Verlag, 15-43, 2008.

Jungclaus, J. H., Haak, H., Latif, M., and Mikolajewicz, U.: ArcticNorth Atlantic interactions and multidecadal variability of the meridional overturning circulation, J. Climate, 18, 4013-4031, 2005.

Jungclaus, J. H., Keenlyside, N., Botzet, M., Haak, H., Luo, J.J., Latif, M., Marotzke, J., Mikolajewicz, U., and Roeckner, E.: Ocean circulation and tropical variability in the coupled model ECHAM5/MPI-OM, J. Climate, 19, 3952-3972, 2006.

Jungclaus, J. H., Lorenz, S. J., Timmreck, C., Reick, C. H., Brovkin, V., Six, K., Segschneider, J., Giorgetta, M. A., Crowley, T. J., Pongratz, J., Krivova, N. A., Vieira, L. E., Solanki, S. K., Klocke, D., Botzet, M., Esch, M., Gayler, V., Haak, H., Raddatz, T. J., Roeckner, E., Schnur, R., Widmann, H., Claussen, M., Stevens, B., and Marotzke, J.: Climate and carbon-cycle variability over the last millennium, Clim. Past, 6, 723-737, doi:10.5194/cp-6723-2010, 2010.

Kanzow, T., Cunningham, S. A., Johns, W. E., Hirschi, J. J.-M., Marotzke, J., Baringer, M. O., Meinen, C. S., Chidichimo, M. P., Atkinson, C., Beal, L. M., Bryden, H. L., and Collins, J.: Seasonal variability of the Atlantic meridional overturning circulation at 26.5 degrees N, J. Climate, 23, 5678-5698, 2010.

Köhl, A.: Anomalies of meridional overturning: Mechanisms in the North Atlantic, J. Phys. Oceanogr., 35, 1455-1472, 2005.

Köhl, A. and Stammer, D.: Variability of the meridional overturning in the North Atlantic from the 50-year GECCO state estimate, J. Phys. Oceanogr., 38, 1913-1930, 2008.

Langehaug, H. R., Medhaug, I., Eldevik, T., and Ottera, O. H.: Arctic/Atlantic exchanges via the subpolar gyre, J. Climate, 25, 2421-2439, 2012a.

Langehaug, H. R., Rhines, P. B., Eldevik, T., Mignot, J., and Lohmann, K.: Water mass transformation and the North Atlantic Current in three multicentury climate model simulations, J. Geophys. Res., 117, C11001, doi:10.1029/2012JC008021, 2012b.

Latif, M., Roeckner, E., Botzet, M., Esch, M., Haak, H., Hagemann, S., Jungclaus, J., Legutke, S., Marsland, S., Mikolajewicz, U., and Mitchell, J.: Reconstructing, monitoring and predicting decadal-scale changes in the North Atlantic thermohaline circulation with sea surface temperature, J. Climate, 17, 1605-1614, 2004.

Latif, M., Böning, C., Willebrand, J., Biastoch, A., Dengg, J., Keenlyside, N., Schweckendiek, U., and Madec, G.: Is the thermohaline circulation changing?, J. Climate, 19, 4631-4637, 2006.

Levermann, A. and Born, A.: Bistability of the Atlantic subpolar gyre in a coarse-resolution climate model, Geophys. Res. Lett., 34, L24605, doi:10.1029/2007GL031732, 2007.

Marti, O., Braconnot, P., Dufresne, J.-L., Bellier, J., Benshila, R., Bony, S., Brockmann, P., Cadule, P., Caubel, A., Codron, F., de Noblet, N., Denvil, S., Fairhead, L., Fichefet, T., Foujols, M.A., Friedlingstein, P., Goosse, H., Grandpeix, J.-Y., Guilyardi, E., Hourdin, F., Idelkadi, A., Kageyama, M., Krinner, G., Lévy, C., Madec, G., Mignot, J., Musat, I., Swingedouw, D., and Talandier, C.: Key features of the IPSL ocean atmosphere model and its sensitivity to atmospheric resolution, Clim. Dynam., 34, 1-26, 2010.

Medhaug, I., Langehaug, H. R., Eldevik, T., Furevik, T., and Bentsen, M.: Mechanisms for decadal scale variability in a simulated Atlantic meridional overturning circulation, Clim. Dynam., 39, 77-93, 2012.

Menary, M., Park, W., Lohmann, K., Vellinga, M., Palmer, M., Latif, M., and Jungclaus, J.: A multimodel comparison of centennial Atlantic meridional overturning circulation variability, Clim. Dynam., 38, 2377-2388, 2012.

Msadek, R. and Frankignoul, C.: Atlantic multidecadal oceanic variability and its influence on the atmosphere in a climate model, Clim. Dynam., 33, 45-62, 2009.

Olsen, S. M., Hansen, B., Quadfasel, D., and Østerhus, S.: Observed and modeled stability of overflow across the Greenland-Scotland ridge, Nature, 455, 519-523, 2008.

Østerhus, S., Sherwin, T., Quadfasel, D., and Hansen, B.: The overflow transport east of Iceland, in: Arctic-Subarctic Ocean Fluxes, edited by: Dickson, R., Meincke, J., and Rhines, P., Springer Verlag, 427-441, 2008:

Otterå, O. H., Bentsen, M., Bethke, I., and Kvamst $\varnothing$, N. G.: Simulated pre-industrial climate in Bergen Climate Model (version 2): model description and large-scale circulation features, Geosci. Model Dev., 2, 197-212, doi:10.5194/gmd-2-197-2009, 2009.

Park, W. and Latif, M.: Multidecadal and multicentennial variability of the meridional overturning circulation, Geophys. Res. Lett., 35, L22703, doi:10.1029/2008GL035779, 2008.

Park, W., Keenlyside, N., Latif, M., Ströh, A., Redler, R., Röckner, E., and Madec, G.: Tropical Pacific climate and its response to global warming in the Kiel Climate Model, J. Climate, 22, 7192, 2009.

Pope, V., Gallani, M., Rowntree, P., and Stratton, R.: The impact of new physical parametrizations in the Hadley Centre climate model - HadCM3, Clim. Dynam., 16, 123-146, 2000.

Serra, N., Käse, R., Köhl, A., Stammer, D., and Quadfasel, D.: On the low-frequency phase relation between the Denmark Strait and the Faroe-Bank Channel overflows, Tellus, 62A, 530-550, 2010.

Servonnat, J., Yiou, P., Khodri, M., Swingedouw, D., and Denvil, S.: Influence of solar variability, $\mathrm{CO}_{2}$ and orbital forcing between 1000 and $1850 \mathrm{AD}$ in the IPSLCM4 model, Clim. Past, 6, 445460, doi:10.5194/cp-6-445-2010, 2010.

Swingedouw, D., Rodehacke, C., Behrens, E., Menary, M., Olsen, S., Gao, Y., Mikolajewicz, U., Mignot J., and Biastoch, A.: Decadal fingerprints of fresh water discharge around Greenland in a multi-model ensemble, Clim. Dynam., doi:10.1007/s00382012-1479-9, 2013.

Tanhua, T., Olsson, K., and Jeansson, E.: Tracer evidence of the origin and variability of Denmark Strait Overflow Water, in: ArcticSubarctic Ocean Fluxes, edited by: Dickson, R., Meincke, J., and Rhines, P., Springer Verlag, 475-503, 2008.

Våge, K., Pickart, R., Spall, M., Moore, G., Valdimarsson, H., Torres, D., Erofeeva, S., and Nilsen, J. E.: Revised circulation scheme north of the Denmark Strait, Deep Sea Res.-Pt. I, 79, 20-39, 2013.

Willebrand, J., Barnier, B., Böning, C., Dieterich, C., Killworth, P. D., Le Provost, C., Jia, Y., Molines, J.-M., and New, A. L.: Circulation characteristics in three eddy-permitting models of the North Atlantic, Prog. Oceanogr., 48, 123-161, 2001. 
Yeager, S. and Danabasoglu, G.: Sensitivity of Atlantic meridional overturning circulation variability to parameterized Nordic Sea overflows in CCSM4, J. Climate, 25, 2077-2103, 2012.

Zanchettin, D., Rubino, A., and Jungclaus, J. H.: Intermittent multidecadal-to-centennial fluctuations dominate global temperature evolution over the last millennium, Geophys. Res. Lett., 37, L14702, doi:10.1029/2010GL043717, 2010.
Zhu, X. and Jungclaus, J. H.: Interdecadal variability of the meridional overturning circulation as an ocean internal mode, Clim. Dynam., 31, 731-741, 2008. 


\section{Appendix A}

\section{Definition of subpolar deep water thickness}

In all models except for BCM, the density range of subpolar deep water is defined based on mean profiles of temperature, salinity and $\sigma_{2}$ (potential density with reference depth $2000 \mathrm{~m}$ ). $\sigma_{2}$ rather than $\sigma$ values are chosen, as Labrador Sea Water in the North Atlantic spreads at a depth of about $2000 \mathrm{~m}$. In MPI-ESM-CR, MPI-AO-LR, KCM and IPSLCM4, profiles are averaged over all integration years and the subpolar $\left(60-10^{\circ} \mathrm{W}, 45-65^{\circ} \mathrm{N}\right)$ grid cells where the MLD in March exceeds $1000 \mathrm{~m}$ in at least $10 \%$ of the integration years. These grid cells correspond approximately to the grid cells where the mean MLD in March exceeds $500 \mathrm{~m}$ (Fig. 2).

In HadCM3, no subpolar grid cells are found, where the MLD in March exceeds $1000 \mathrm{~m}$ in at least $10 \%$ of the integration years. The same is true, if other winter months (December, January, February) rather than March are considered. If all grid cells, where the MLD in March exceeds $1000 \mathrm{~m}$ in at least one integration year, are taken into account, subpolar deep convection is found in the Labrador and Irminger seas. In HadCM3, profiles of temperature, salinity and $\sigma_{2}$ are therefore averaged only over those integration years and subpolar grid cells, when and where the MLD in March exceeds $1000 \mathrm{~m}$.

The upper isopycnal defining subpolar deep water is chosen below the temperature and salinity maximum representing water from the subtropical Atlantic, at a depth of about $800 \mathrm{~m}$. The lower isopycnal is chosen at the beginning of the deep pycnocline, at a depth of about $2500-3000 \mathrm{~m}$. The resulting density range of subpolar deep water for the various models is as follows: $M P I$ ESM-CR: $\sigma_{2}=36.62-36.76 \mathrm{~kg} \mathrm{~m}^{-3}, \quad M P I-A O-L R: \quad \sigma_{2}=$ $36.65-36.77 \mathrm{~kg} \mathrm{~m}^{-3}, K C M: \sigma_{2}=36.90-37.01 \mathrm{~kg} \mathrm{~m}^{-3}, I P-$ SLCM4: $\sigma_{2}=36.76-36.87 \mathrm{~kg} \mathrm{~m}^{-3}$, HadCM3: $\sigma_{2}=36.74$ $37.03 \mathrm{~kg} \mathrm{~m}^{-3}$. The thickness of subpolar deep water we define as the depth interval between the upper and lower isopycnal specifying the density range of subpolar deep water.

For BCM, where an isopycnic vertical coordinate is used, we follow Langehaug et al. (2012a, analysing the same simulation as used in our study), defining the layers with $\sigma_{2}=$ $36.846 \mathrm{~kg} \mathrm{~m}^{-3}$ and $\sigma_{2}=36.946 \mathrm{~kg} \mathrm{~m}^{-3}$ as (upper) Labrador Sea Water. These density layers occupy approximately the depth range between 600 and $1800 \mathrm{~m}$ in the Labrador Sea (Langehaug et al., 2012a; their Fig. 9). The thickness of subpolar deep water we define as the sum of the layer thickness of these two density layers.

\section{Appendix B}

\section{Definition of Nordic Seas overflow transports}

The following criteria are used to define the overflow transport through the Denmark Strait and across the IcelandScotland Ridge in the various models: MPI-ESM-CR: transport out of Nordic Seas for $\sigma>27.76 \mathrm{~kg} \mathrm{~m}^{-3}$ and depth $>300 \mathrm{~m}$ (through Denmark Strait) and for $\sigma>27.8 \mathrm{~kg} \mathrm{~m}^{-3}$ (across the Iceland-Scotland Ridge), MPI-AO-LR: transport out of Nordic Seas for $\sigma>27.8 \mathrm{~kg} \mathrm{~m}^{-3}, K C M$ : transport out of Nordic Seas for $\sigma>27.8 \mathrm{~kg} \mathrm{~m}^{-3}$, IPSLCM4: transport out of Nordic Seas for $\sigma>27.75 \mathrm{~kg} \mathrm{~m}^{-3}$, HadCM3: transport out of Nordic Seas for depth $>300 \mathrm{~m}$, and BCM: net transport for $\sigma_{2}>36.946 \mathrm{~kg} \mathrm{~m}^{-3}$ (corresponding to about $\sigma$ $>27.83 \mathrm{~kg} \mathrm{~m}^{-3}$ ). The transport is restricted to depth levels greater than $300 \mathrm{~m}$ in some of the models to ensure a separation between the Denmark Strait overflow and the lower East Greenland Current. In $B C M, \sigma_{2}$ isopycnal layers are used as the vertical coordinate in the ocean component. Therefore, the density threshold is specified as the $\sigma_{2}$ value. In this model, also the net transport rather than the transport out of the Nordic Seas is used. We note, however, that this difference is negligible, as a transport into the Nordic Seas with the given density threshold generally does not exist. 